\title{
Ellipsis
}

2017

\section{The Narrative Structure of Wuthering Heights: An Examination of Nelly Dean and Lockwood}

Natacha Bensoussan

Follow this and additional works at: https://scholarworks.uno.edu/ellipsis

\section{Recommended Citation}

Bensoussan, Natacha (2017) "The Narrative Structure of Wuthering Heights: An Examination of Nelly Dean and Lockwood," Ellipsis: Vol. 44 , Article 24.

DOI: https://doi.org/10.46428/ejail.44.24

Available at: https://scholarworks.uno.edu/ellipsis/vol44/iss1/24

This Literary Criticism is brought to you for free and open access by the Department of English and Foreign Languages at ScholarWorks@UNO. It has been accepted for inclusion in Ellipsis by an authorized editor of ScholarWorks@UNO.For more information, please contact scholarworks@uno.edu. 


\title{
The Narrative Structure of Wuthering Heights: An Examination of Nelly Dean and Lockwood
}

\author{
Natacha Bensoussan
}

\section{Catherine Barragy Mackin Memorial Prize Winner}

Emily Brontë's Wuthering Heights is one of the most critiqued novels in the English language. The most fascinating aspect of this great work is its unique, multi-layered narrative structure. Brontë uses the literary technique of a dual narrative - a form of narrative that incorporates two different perspectives from two different individuals at varying points in time - to directly engage her readers by creating distance and objectivity. Incorporating traditional methods employed by the oral tradition that rely heavily on dialogue and delivery, Brontë's structural approach allows the novel to progress fluidly despite any difficulties presented by the obscure shifts in time.

At first glance, the primary narratives are apparently delivered by Lockwood and Nelly Dean. Although a number of other narratives exist within the larger frameworks of their accounts, it is the perspectives of these two characters that shape the story. Lockwood's narrative is the outer framework of the novel which incorporates the intimate, eyewitness account of Nelly's story, who, in turn, relates the tertiary narratives of other characters. In addition to this basic structure, the traits and comments of each narrator is a vital aspect of understanding the text. McCarthy suggests, therefore, that it is important to view the narrators of Wuthering Heights as crucial mediums rather than simple structural and narrative tools: consideration of their mental framework, backgrounds, experiences of the world and subsequent points of view, reveals each character as an individual force that helps shape and influence Brontë's novel.

Lockwood's heterodiegetic narration - one in which the narrator is not a character but an outsider - provides a framework for the story (Barry 226). While the reader understands that he narrates the majority of the novel on some level, his presence, lost in the transcription of Nelly Dean's tale, is nearly indiscernible. Noting that Nelly "is, on the whole, a very fair narrator," and that he "[doesn't] think [he] could improve her style," he decides not to stray from her story except to condense when necessary (Brontë 165). The incorporation of Lockwood's unique persona allows Brontë to navigate the difficult task of starting toward the end of the primary action, so that she may circle back to the beginning with relative ease. Written in the format of a personal diary, the first few chapters of the novel are narrated by Lockwood himself, posing as an introduction to the $19^{\text {th }}$ century world and setting in which Wuthering Heights takes place. It also serves to create an underlying sense of intimacy between him, an impartial character, and the reader. Although few details about his character are presented outright, the cognizance of his personal medium informs the reader that special attention must be paid to Lockwood's comments. In addition to the first and last chapters in the novel, it is only in between brief breaks in Nelly's narrative that 
Lockwood's voice is heard directly, allowing the reader to ferret out what sort of character the bulk of information comes from.

In order to understand Lockwood and his motives, close attention must be paid to what he says through what he conceals. When considering the motives and traits that make up the narrators, it is important to remember that this "novel situates itself in the play between... nonexclusive fields, in the space of indeterminacy between margin and text" so that "the overt content of the marginal narratives gives place to the texts embedded between their lines" (London 35). Here, Bette London suggests that by zeroing in and focusing on the seams of each narrator, considered the 'margins,' rather than the presentation of their narrative as whole, or the 'text,' by reading between the lines of what is said or interpreting the importance of what is left unsaid, the reader gains more insight into the overall significance. Although Lockwood is nearly invisible for the majority of the story, what little he does share in his observations about others is crucial. Lockwood, the self-proclaimed misanthrope from a "busy-town," comes off as a pompous intellectual. Clearly educated, the sophisticate employs elevated, descriptive language in long sentences that are often complex and punctuated by a series of semi-colons, dashes, and clauses, that is at odds with the colloquial dialect of the Heights and constantly reinforces his presence as 'other.' Using logic as a shield, he fancies himself someone of "respectable character," yet the facade of cultivated English politeness is unexpectedly tested when he enters a world that is both bewilderingly aggressive and foreign (Brontë 312). Not surprisingly, he is fascinated by what he encounters, even though it leaves him feeling uncomfortable. Instead of absorbing what he experiences with an open mind, he views his surroundings with the preconceived notions of high-brow society, perplexed by how unconcerned the rural world of Wuthering Heights is in terms of gentility. Brontë chooses the one character who is incapable of being alone to reveal a major theme of the novel: the irrevocable effects of both locational and emotional isolation on individuals, and the raw passions that may erupt as a result.

It is "Lockwood's fickleness and ignorance of his own character [that] make him a thoroughly unreliable narrator, for he judges others according to his own ideas of himself" (McCarthy 51). Whether in $19^{\text {th }}$ century England or the $21^{\text {st }}$ century, individuals - especially those of an elite upper class - tend to draw broad comparisons between themselves and others, either to ensure that they are not violating the norms of societal decorum or to reassure themselves of their own superiority. Lockwood is concerned with both. For example, when musing about Heathcliff during his first visit to the Heights, Lockwood states, "he'll love and hate, equally under cover, and esteem it a species of impertinence, to be loved or hated again - no, I'm running too fast - I bestow my own attributes over-liberally on him" (Brontë 39). This also suggests an inadequacy of self in which Lockwood hopes to find the qualities he wishes to emulate in an equal. Yet, with an upturned nose, the presumptuous gentleman often belittles other characters with descriptors like "under-bred," "rustic," "uncultivated," and "shabby," thwarting the unconscious desire to belong by focusing on the appearance of things rather than what lies beneath. Whether incapable or uninterested in navigating the unknown, he continuously distances himself from that which cannot understand. Despite his 
amusing self-awareness, Lockwood is at his core an emotional cripple whose transparent "inability to engage his feelings...to act or feel" exposes a vapidness that is in stark contrast with the other characters of the novel (London 38). As his "emptiness is exposed, [and we begin to] reject the [primary] narrator, Wuthering Heights seems less and less forlorn," working to Brontë's favor by redistributing traditional judgment and adding weight to the emotionally charged actions of the characters he writes about (McCarthy 54).

Lockwood is an outsider, which is what distinguishes him from the novel's secondary narrator, Nelly Dean. Unlike the former, whose role is simply playing the 'recorder,' Nelly's narration is homodiegetic: she is a character who is present for and participates in the action of the story she narrates (Barry 265). Bell likens Nelly's narrative to an English folk ballad in which her limited point of view is "heard" rather than "read" by Lockwood, focusing on central action rather than nonessential details that would obscure the story (200). The absence of such embroidery allows Brontë to focus primarily on characterization without incorporating her voice as the author. Presented with near breathless efficiency, Nelly's technique is packed with energy and vivid details since, like the ballad, "...there is only one chance to convey the desired impression" (Bell 200). As the vehicle in which we receive the story, her narrative differs from Lockwood's in that it consists primarily of dialogue, often true to the different dialects and idioms of the Heights' inhabitants. Nelly's personal speech, while elevated from that of an average servant in rural England, remains colloquial and approachable. Using shorter, less complex sentences than Lockwood, her story is life-like and imaginative, bursting with a sense of urgency as if she were relating events that transpired a few hours prior, rather than in years past. Given that Nelly's heavily dramatized narrative does not contain any editorial comments or premeditated introductions, the impact is more powerful than Lockwood's narration. As the events tumble out of the natural gossip's mouth and into Lockwood's diary, the reader's opinions, warped and uncertain, fluctuate wildly. Bell asserts that "dialogue, however, only suggests what is beneath the surface; to penetrate deeper, to explore the more subtle psychological and emotional states that are only intimated in dramatic actions, [Brontë] resorts to an adroit use of monologue, and... to Nelly's faithful reporting" (207). As riveting as her report may be, Nelly is a character in the story she is presenting, and her perception is therefore questionable.

It is important to remember that Nelly's past, present, and future are irrevocably intertwined with the land and people she details. Just as Heathcliff and Catherine are altered by their relationship with one other, her character is molded by circumstance and association with the others. In her formative years, her precarious position as foster-child and playmate is toppled by the threatening arrival of Heathcliff who, doted on by her master, is immediately recognized as more of a family member than she is. Signaling the end of Nelly's childhood, his presence forces her to pick sides, adopt the role of caretaker, and fully embrace her inherited responsibility as a servant. In adulthood, she is banished from her home at the Heights and cut off from her foster-son, Hareton, by the very individual who disrupted her youth. She is compelled to attend to Catherine 
instead, a woman she openly disdains. Not only is Nelly continuously subjected to the whims and follies of others, but she remains the only character who is unable to live up to her biological function as a human being, sexually and socially excluded from the realm of courtship, love, and marriage. While she attempts to retain some sense of equality through self-education, Nelly ultimately forfeits her studie's knowing she has reached an intellectual impasse. It is "loses...pains, and humiliations [like these]," Groove explains, that reveal how the semi-educated housekeeper's first hand involvement in the story skews her objectivity and solidifies her as an unreliable narrator. As “the poor man's daughter," Nelly's social status and subsequent hardships are a major guiding force in the novel (Brontë 87).

Like Lockwood, who perceives Nelly Dean as a curious human object belonging to the Grange, most critics overlook the affect her position and age have on the story. Yet it is crucial to understand that Nelly, a lonely, dispossessed servant isolated from society at large, has been given a voice for the first time. Once she begins her account - on behalf of a flattering stranger who cannot contradict her - it is no surprise that the subtext begins to detail the psychological consequences of the trials listed above. In some ways, Nelly's narrative can also be interpreted as the story of her life. Her accounts are subject to partiality, often benefiting from alterations, edits, self-amnesty and justification, as she colors and shapes the story to suit her. These accounts, Volger observers, are "committed to a chronological matrix [based on] her own experiences, [and reflect] the basic reality of her life..." (90). Her presentation is dependent upon the inherent meaning she gathers from each event, and without a personal frame of reference, she would be unable to recreate a chronological timeline. Nelly's attitude toward life is quite linear as a result.

Intrinsically conservative and filled with resentment, Nelly exists in a constant state of insecurity, uncertain of her role and how she will be received by others. As a result, her "ruthless efforts to hold her 'place' in a household where she is (yet is not) more than a servant... outline... struggles for status and possession" (Grove 40). In spite of the struggle to understand and or verbalize the events that transpire around her due to a lack of "intellectual equipment for analysis" and limitations of class, Nelly's "faithful, if improbable, rendering of dialogue does the job for her" (Bell 206). The scenes she focuses on in her narrative are selected with such precision that the reader, perceiving the essential spirit of the novel, can deduce the psychological aspects of each character. It is through these renditions of dialogue that the self-proclaimed "sensible soul" communicates who she is, interjecting her personal and religious beliefs through a pseudo-stoic story (Brontë 135).

Nelly's favorable opinion of herself as a "stout and reasonable kind of body" is not entirely unfounded, though (Brontë 87). Her role as confidant, as well as the level of dependency each character exhibits for her, reinforces this belief. While Nelly does display altruistic tendencies at times, they only extend so far. Due to a continued sense of familiarity and the breach of master-servant relationships that transpire, Tytler explains that "Nelly is not averse to using the troubles of her superiors as a means of pointing up the intelligence and sobriety of 
her own mode of existence" and that by shedding light on "the moral defects or foibles of [the other characters], [she] makes herself appear, by contrast, the essence of normality and good sense..." $(231,232)$. Brontë utilizes Nelly's often ambivalent attitude, in addition to Nelly's tendency to meddle in other people's affairs and pass judgment, to reveal her hypocrisy and moral inconsistency. With help from Lockwood, who provides distance and objectivity, Brontë's ultimate narrative tool is "Nelly's judgment... [which reveals] how facile and incompetent human judgment can be" (Bell 208).

Drawing heavily on the oral tradition, the dual narrative utilized by Brontë engages her readers in a dramatic see-saw to create the effect of real-time action despite major shifts in time. McCarthy suggests that the author incorporates the "two distorted view points" of her unreliable narrators, each suffering from the effects of their socioeconomic positions and subsequent emotional states, to lessen the impact of the otherwise cruel and morally defunct actions of the primary characters. By removing her voice as an author and replacing it with the strong, emotive language of Lockwood and Nelly Dean, Brontë allows the story to speak entirely for itself. This tactic, in turn allows the reader to recognize their errors and focus more on understanding the tale rather than judging it by suggesting the personal failings of her narrators. Coming to the realization that the narrators are simple tools rather than personas who should be taken literally, then, the reader is able formulate their own opinions by the end of the novel. Brontë's alteration of traditional techniques of oral narrative, delivered by the misguided narration of Lockwood and Nelly Dean, serves to immortalize the key players, elevating them above moral and ethical judgment so that their story transcends time.

\section{Works Cited}

Barry, Peter. Beginning Theory: An Introduction to Literary and Cultural Theory. $3^{\text {rd }}$ ed., Manchester University Press, 2009.

Bell, Vereen. "Wuthering Heights as Epos." College English, vol. 25, no. 3, Dec., 1963, pp. 199- 208.

Brontë, Emily. Wuthering Heights. Broadview Editions, 2007.

Grove, Robin. “The Poor Man's Daughter's Tale: Narrative and System in Wuthering Heights." The Critical Review, no. 36, 1996, pp. 32-40.

London, Bette. "Wuthering Heights and the Text Between the Lines." Papers on Language \& Literature, vol. 24, no. 1, 1988, pp. 34-52.

McCarthy, Terence. "The Incompetent Narrator of Wuthering Heights." Modern Language Quarterly, vol. 42, no.1, 1981, pp. 48-64.

Tytler, Grame. "The Parameters of Reason in Wuthering Heights." Bronte Studies, vol. 30 , no. 3 Nov. 2005 , pp. 231-241

Vogler, Thomas A. "Story and History in Wuthering Heights." Twentieth-Century Interpretations of Wuthering Heights, edited by Thomas Vogler, Prentice Hall, 1968, pp. 78-99. 